\title{
JA030507K
}

\section{The Energetics of Phosphate Binding to}

\section{Ammonium and Guanidinium Containing}

\section{Metallo-Receptors in Water}

\author{
Suzanne L. Tobey and Eric V. Anslyn* \\ Department of Chemistry and Biochemistry, The University of Texas, Austin, TX 78712 \\ anslyn@ccwf.cc.utexas.edu
}

\section{Experimental}

\section{General Considerations}

The chemicals used were obtained from Aldrich and were used without further purification, except where noted. Methanol was refluxed over magnesium and distilled. Flash chromatography was performed on Whatman $60 \AA$ 230-400 mesh silica gel. ${ }^{1} \mathrm{H}$ (300 MHz) and ${ }^{13} \mathrm{C}(75 \mathrm{MHz})$ spectra were measured by Varian Unity Plus spectrometer. Mass spectra were recorded on a Finnigan VG analytical ZAB2-E spectrometer. 


\section{UV/Vis Titrations}

The titrations were performed on a Beckman DU-640 UV/Vis instrument. A typical titration is described below, though concentrations varied from experiment to experiment. A solution of the host $(5.12 \mathrm{mM})$ was prepared and buffered with TRIS $(10 \mathrm{mM})$ at $\mathrm{pH}$ 7.4. A similar solution of the guest $(52.29 \mathrm{mM})$ was prepared. A cuvette was then filled with $770 \mu \mathrm{L}$ of a TRIS $(10 \mathrm{mM})$ solution and scanned as the blank reading. $230 \mu \mathrm{L}$ of the host solution was introduced to the cuvette (total host concentration of $1.17 \mathrm{mM}$ ) and the absorbance recorded. Aliquots of a stock solution were then added to the cuvette and the absorbance recorded after each addition. The stock solution contained the host (1.17 $\mathrm{mM})$ and guest $(19.86 \mathrm{mM})$ in TRIS buffer $(10 \mathrm{mM})$. The absorbances for each addition, at a chosen wavelength, were used to calculate the delta absorbances relative to the first absorbance reading. These values were then plotted versus the concentration of the added guest for each aliquot. The binding isotherm from this raw data was curve fit using the 1:1 binding equation (either done manually in Excel or done iteratively in Origin).

\section{Isothermal Titration Calorimetry}

The titration apparatus was purchased from Microcal Inc. The VP-ITC instrument is interfaced with Origin (version 5) software for both data collection and data analysis. A typical titration is described, though concentrations, buffers, and parameters varied from experiment to experiment. The reference cell was filled with a buffer solution (HEPES 5 $\mathrm{mM}$ ) identical to that in the titration cell. The titration cell was filled with a HEPES buffered ( $5 \mathrm{mM}, \mathrm{pH} 7.4)$ solution of the host $(0.82 \mathrm{mM})$. Exactly the same stock solution 
of buffer was used in the cell and the titrant to avoid problems associated with heat evolved from changes in buffer protonation state during the titration. The syringe was filled with approximately $250 \mu \mathrm{L}$ of a solution of the guest $(19.94 \mathrm{mM})$ buffered with HEPES (5 mM, pH 7.4). The ionic strength of the solution is controlled by the buffer, which is at least 5 fold the concentration of the contents of the cell. The concentration of the syringe contents is typically 20 times that of the concentration of the cell contents. The syringe was fitted above the cell and the following parameters set: Injection size : 5 $\mu \mathrm{L}$, Number of injections: 43 , Temperature: $25^{\circ} \mathrm{C}$, Injection Interval: $300 \mathrm{sec}$, Cell Feedback: $20 \mu \mathrm{cal}$. Following data collection the Origin software was used to apply a 1:1 binding algorithm to the data, the fit of which yields a binding affinity, enthalpy change, entropy change and binding stoichiometry for the titration.

\section{pH Titrations}

The titration data were collected using an DOS based program (Iassist) interfaced with an Orion 720A pH meter and a Harvard Apparatus 55-2222 syringe pump. The $\mathrm{pH}$ electrode was purchased from Orion, PerpHecT Ross Electrode Model:8203BN. The concentrations of the $\mathrm{NaOH}(83.5 \mathrm{mM})$ and $\mathrm{HCl}(130.24 \mathrm{mM})$ solutions were determined by titrations with potassium hydrogenphtalate using phenolphthalein as the indicator. The substrate $(0.005 \mathrm{mmol})$ was added to an aqueous solution $(5 \mathrm{~mL})$ containing $\mathrm{NaCl}$ $(20 \mathrm{mM})$ and $\mathrm{HCl}(0.065 \mathrm{mmol})$. Aliquots $(10 \mu \mathrm{L})$ of $\mathrm{NaOH}$ were added and $\mathrm{pH}$ 
readings were taken 60 seconds after addition. On average $80-100$ data points were recorded. The collected data were fit using HYPERQUAD.

\section{2,6-monobromomethylazidomethypyridine(4)}

To a solution of 2,6-bisbromomethylpyridine $(3.67 \mathrm{~g}, 13.8 \mathrm{mmol})$ in dry $\mathrm{N}, \mathrm{N}$ dimethyformamide $(80 \mathrm{~mL})$ was added $\mathrm{NaN}_{3}(0.27 \mathrm{~g}, 4.1 \mathrm{mmol})$. The reaction mixture was stirred under argon for five days at room temperature. The solvent was removed in vaccuo, and the residue suspended in $\mathrm{CH}_{2} \mathrm{Cl}_{2}$. The suspension was filtered through celite,

dried with $\mathrm{Na}_{2} \mathrm{SO}_{4}$ and concentrated to yield a yellow oil. After flash chromatography on silica gel, eluting with $\mathrm{CH}_{2} \mathrm{Cl}_{2}$, a colorless oil was obtained (0.64 g, $\left.2.8 \mathrm{mmol}\right)$ in $67 \%$ yield. The starting material was recovered.

${ }^{1} \mathrm{H}$ NMR $\left(\mathrm{CDCl}_{3}\right): \delta 7.69(\mathrm{t}, 1 \mathrm{H}), 7.35(\mathrm{~d}, 1 \mathrm{H}), 7.24(\mathrm{~d}, 1 \mathrm{H}), 4.50(\mathrm{~s}, 2 \mathrm{H}), 4.44(\mathrm{~s}, 2 \mathrm{H})$.

${ }^{13} \mathrm{C}$ NMR $\delta 156.78,155.66,138.01,122.62,121.08,55.29,33.44$. HRMS $(\mathrm{CI}+) \mathrm{m} / \mathrm{z}$ 226.9938; calcd. 226.9932.

\section{Tris-(6-azidomethyl-pyridin-2-ylmethyl)amine (5)}

To a solution of 2,6,-monobromomethylazidomethypyridine $(0.83 \mathrm{~g}, 3.65 \mathrm{mmol})$ in dry $\mathrm{CH}_{3} \mathrm{CN}(30 \mathrm{~mL})$ was added $\mathrm{NH}_{4} \mathrm{OAc}(84 \mathrm{mg}, 1.1 \mathrm{mmol})$ and $\mathrm{K}_{2} \mathrm{CO}_{3}(0.30 \mathrm{~g}, 2.2 \mathrm{mmol})$ as solid portions. The suspension was stirred under argon for seven days at room temperature. The reaction mixture was filtered through a pad of celite, dried with $\mathrm{Na}_{2} \mathrm{SO}_{4}$, and concentrated to yield an oil. Purification using flash chromatograpy on 
silica gel (eluent $\mathrm{CH}_{2} \mathrm{Cl}_{2}$ to $5 \% \mathrm{NH}_{3}$ sat'd $\mathrm{MeOH}$ in $\mathrm{CH}_{2} \mathrm{Cl}_{2}$ ) yielded the product as an oil $(0.40 \mathrm{~g}, 0.89 \mathrm{mmol})$ in an $81 \%$ yield.

${ }^{1} \mathrm{H} \mathrm{NMR}\left(\mathrm{CDCl}_{3}\right): \delta 7.64(\mathrm{t}, 3 \mathrm{H}), 7.53(\mathrm{~d}, 3 \mathrm{H}), 7.16(\mathrm{~d}, 3 \mathrm{H}), 4.40(\mathrm{~s}, 6 \mathrm{H}), 3.87(\mathrm{~s}, 6 \mathrm{H})$.

${ }^{13} \mathrm{C}$ NMR $\delta 159.01,155.25,137.34,122.13,120.18,59.93,55.48$. HRMS (CI+) $\mathrm{m} / z$ 456.2120; calcd. 456.2121. IR (2102 $\left.\mathrm{cm}^{-1}\right)$

\section{Tris-(6-aminomethyl-pyridin-2-ylmethyl)-amine (6)}

To a solution of tris-(6-azidomethyl-pyridin-2-ylmethyl)amine $(0.28 \mathrm{~g}, 0.61 \mathrm{mmol})$ in tetrahydrofuran $(4.8 \mathrm{~mL})$ was added triphenylphosphine $(0.56 \mathrm{~g}, 2.13 \mathrm{mmol})$ and water $(0.3 \mathrm{~mL})$. The reaction mixture was stirred at room temperature for $4 \mathrm{hrs}$. The reaction mixture was concentrated, and the residue dissolved in water $(10 \mathrm{~mL})$ and $\mathrm{CH}_{2} \mathrm{Cl}_{2}(10 \mathrm{ml})$. The $\mathrm{pH}$ was adjusted to 1 using $2 \mathrm{M} \mathrm{HCl}$ and the organic layer separated. The aqueous layer was washed with $\mathrm{CH}_{2} \mathrm{Cl}_{2}(3 \times 10 \mathrm{~mL})$. The $\mathrm{pH}$ of the aqueous layer was adjusted to 10 using $2 \mathrm{M} \mathrm{NaOH}$ and extracted several times with $\mathrm{CH}_{2} \mathrm{Cl}_{2}$. The organic layer was concentrated to a yellow oil $(0.13 \mathrm{~g}, 0.34 \mathrm{mmol})$ in a $56 \%$ yield.

${ }^{1} \mathrm{H}$ NMR $\left(\mathrm{CD}_{3} \mathrm{OD}\right): \delta 7.72(\mathrm{t}, 3 \mathrm{H}), 7.53(\mathrm{~d}, 3 \mathrm{H}), 7.24(\mathrm{~d}, 3 \mathrm{H}), 3.86(\mathrm{~s}, 6 \mathrm{H}), 3.85(\mathrm{~s}, 6 \mathrm{H})$.

${ }^{13} \mathrm{C}$ NMR $\delta 161.55,159.74,138.65,122.41,120.95,61.00,47.62 . \mathrm{HRMS}(\mathrm{CI}+) \mathrm{m} / \mathrm{z}$ 378.2413; calcd. 378.2406. IR (3355 $\left.\mathrm{cm}^{-1}\right)$

\section{Tris-(6-[[(1,1-dimethylmethoxy)carbonyl]methylamino]-pyridin-2-ylmethyl)- amine (7)}

To a solution of tris-(6-aminomethyl-pyridin-2-ylmethyl)-amine $(0.23 \mathrm{~g}, 0.61 \mathrm{mmol})$ in ethanol $92.7 \mathrm{~mL}$ ) was added $\mathrm{N}$-(t-butoxycarbonyl)-2-thiomethyl-2-imidazoline (0.45 g, 
$2.2 \mathrm{mmol})$ and acetic acid $(0.3 \mathrm{~mL})$. The reaction mixture was stirred at $50 \mathrm{C}$ for $4 \mathrm{hrs}$. The reaction mixture was concentrated and purified by flash column chromatography (silica) with a gradient of $1-5 \% \mathrm{NH}_{3}$ saturated methanol in $\mathrm{CH}_{2} \mathrm{Cl}_{2}$. The product was isolated as a brown oil ( $0.24 \mathrm{~g}, 0.26 \mathrm{mmol})$ in a $44 \%$ yield.

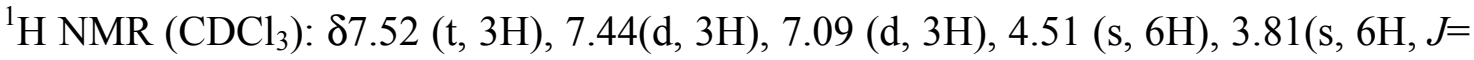
8.4 Hz), 3.69(m, 6H,), 3.59(m, 6H), 1.42(s, 27H). ${ }^{13} \mathrm{C}$ NMR $\delta 159.10,156.45,136.89$, 121.17, 119.57, 81.88, 59.96, 53.34, 28.26. HRMS (CI+) $m / z$ 882.5102; calcd. 882.5102.

\section{Tris-(6[(4,5-dihydro-1H-imidazol-2-yl)methylamino]-pyridin-2-ylmethyl)-amine}

To a solution of tris-(6-[[(1,1-dimethylmethoxy)carbonyl]methylamino]-pyridin-2ylmethyl)-amine $(0.11 \mathrm{~g}, 0.124 \mathrm{mmol})$ in $\mathrm{CH}_{2} \mathrm{Cl}_{2}(1 \mathrm{~mL})$ was added trifluoroacetic acid $(0.3 \mathrm{~mL})$. This was stirred at ambient temperature for 12 hours. The reaction mixture was concentrated and toluene $(2 \mathrm{~mL})$ was added. The mixture was then concentrated under reduced pressure. The residue was dissolved in water an liopholized to yield a cream colored sold. This was passed through an acetate anion exchange column. The eluent

was liopholized and observed by ${ }^{1} \mathrm{H}$ NMR to ensure the quantitative exchange of the trifluoroacetate ions. The acetate salt was then passed through a chloride anion exchange column to yield a solid (80 mg, $0.11 \mathrm{mmol})$ in a 94\% yield. 
${ }^{1} \mathrm{H}$ NMR $\left(\mathrm{CD}_{3} \mathrm{OD}\right): \delta 7.79(\mathrm{t}, 3 \mathrm{H}), 7.56(\mathrm{~d}, 3 \mathrm{H}), 7.28(\mathrm{~d}, 3 \mathrm{H}), 4.51(\mathrm{~s}, 6 \mathrm{H}), 3.90(\mathrm{~s}, 6 \mathrm{H})$, 3.72(s, $12 \mathrm{H}) .{ }^{13} \mathrm{C}$ NMR $\delta 159.38,155.15,138.53,138.41,122.85,120.60,65.20,60.24$, 48.11, 44.01. HRMS (CI+) $m / z$ 688.26.32; calcd. 688.26. 